\title{
Physico-Mechanical Properties of Particleboards Produced from Locally Sourced Materials
}

\author{
Ikubanni, Peter Pelumi ${ }^{1, a^{*}}$, Adeleke, Adekunle Akanni ${ }^{2, b}$ \\ Adediran, Adeolu Adesoji ${ }^{3, \mathrm{c}}$ and Agboola, Olayinka Oluwole ${ }^{4, \mathrm{~d}}$
}

1,3,4 Department of Mechanical Engineering, Landmark University, Omu-Aran, Kwara State, Nigeria.

${ }^{2}$ Department of Mechanical Engineering, University of Ilorin, Ilorin, Kwara State, Nigeria.

a*ikubanni.peter@Imu.edu.ng, ’adeleke.kunle@ymail.com, 'cadediran.adeolu@Imu.edu.ng,

aaboola.olayinka@Imu.edu.ng

Keywords: Particleboard, rice husks, saw dust, mechanical properties, composites, physical Properties

\begin{abstract}
In this study, particleboard was produced from the blend of sawdust and rice husk with the inclusion of metallic chips and adhesives. Urea formaldehyde and gelatinous starch were used as adhesives. Particleboards (10 mm thickness) were made from varying weight percentage ratio of saw dust and rice husk using pressure in the neighbourhood of $3 \mathrm{~N} / \mathrm{mm}^{2}$. The particleboard was tested to determine the density, modulus of rupture (MOR), modulus of elasticity (MOE) and internal bonding strength (IBS). The density of the particleboards developed varies from 762.86 to $801.60 \mathrm{~kg} / \mathrm{m}^{3}$. The moisture content of the samples varied between $9.22 \%$ and $9.98 \%$. The MOR, MOE and IB values varied between 5.08 MPa and 26.08 $\mathrm{MPa}$; $75.38 \mathrm{MPa}$ and $412.4 \mathrm{MPa}$; and $0.013 \mathrm{MPa}$ to $0.07 \mathrm{MPa}$, respectively. Composite samples $\mathrm{C}, \mathrm{E}$ and $\mathrm{H}$ values for MOR, MOE and IBS gave significant results which met with the EN, ANSI A 208.1 and USDA standards. Hence, the admixture of rice husk and sawdust together with UF adhesive will be suitable in producing particleboard that could be useful for indoor and outdoor purposes.
\end{abstract}

\section{Introduction}

The replacement of solid wood particles with agro-wastes in the manufacture of particleboard is a recent alternative to particleboard production. Residues from agricultural materials such as rice husks, cornstalks and corncobs, cereal straw, sunflower stalks and so on can be an alternative in particleboard production [1]. The production of panel products from agricultural residues is important considering the increasing wood fiber shortage all over the world [2]. Of all the agricultural residues in Nigeria, rice husk is readily available and thus can be considered as an excellent raw material to manufacture particleboard [3]. However, little portion of the rice husks produced are utilized in animal feed formulation while larger amount are burnt or dumped as a solid waste [4]. Hence, the use of rice husk will therefore eliminate disposal problem experienced by rice milling industries.

Sawdust is another by-product from the huge consumption of forest reserves which are often discarded also as waste [5]. The yearly generation are in millions of ton [6]. The usual prevalent habit of getting rid of the waste in Nigeria is by burning and this is hazardous to the environment and human health [6]. Similar to the rice husk, the problem of saw dust disposal can be overcome by utilising it in the production of particleboards

In addition, to turn these wastes to wealth will consequently improve the economic base of Nigeria among the committee of developing nations of the world. Liu et al. [7] investigated the potential uses of rice husk in the production of animal feeds, bedding materials, soil conditioner, fertilizer, bio-fuel, organic inorganic chemicals, carbon, abrasives components, refractory insulating materials, paper board manufacturing. A comprehensive review of the potential of rice husk ash was carried out in which rice husk as can be used as a pozzolanic material, as an absorbent and as a source for silica. Ajiwe et al. [8] and Melo et al. [9] carried out an assessment of particleboards 
manufactured from different proportions of wood and rice husk particles and reported that the particleboard had insufficient strength due to poor bonding within the admixture. According to Omoniyi [10], rice husk contains high concentration of silica in amorphous crystalline (quartz) forms. The presence of amorphous silica determines the pozzolanic effect of rice husk. Pozzolanic effect exhibits cementitious properties that increase the rate at which the material gains strength. The degree of strength depends upon the chemical composition of alumina silica in the material. As observed by Problete [11], the production particleboard panels require combination of wood particles (wood chips or saw dust) and, rice husks with suitable binders while applying pressure in the presence or absence of heat [11]. Physical and mechanical properties of particleboards manufactured with wood, rice husk and bamboo particles in different combinations were assessed by Melo et al. [12]. It was reported that the quality of bamboo-based particle board was better than that of rice husk particle board. Based on the result obtained from the characterization of the manufactured particleboards where the physical and mechanical properties were determined, rice husk caused reduction in particle board quality. Moreover, particleboards manufactured exclusively with wood particles showed similar performance to bamboo and wood-bamboo particleboards. Laemlaksakul [4] examined the mechanical and physical properties of particle board obtained from bamboo in determining the influence of particle board density $\left(600,700\right.$ and $\left.800 \mathrm{~kg} / \mathrm{m}^{3}\right)$ and temperature of condition $\left(25,40\right.$ and $\left.55^{\circ} \mathrm{C}\right)$. It was reported that bamboo waste could be used in particleboard production. The use of industrial wastes such as metallic chips to produce unique particleboard with magnetic properties to improve on the existing particleboards is a major focus of the present study. In addition, the development of particleboard from agro-waste materials has not been well established in Nigeria, thus incremental research activity is hence needed in a bid to establish optimum composition mix for such agro constituents. Therefore, the aim of the present work is to assess the viability of using industrial and agro-wastes as potential materials in the development of particleboards for both indoor and outdoor application.

\section{Materials and Method}

\section{Materials}

Locally sourced rice husks, metallic chips, sawdust, urea formaldehyde (50\% solid content) and gelatinised starch $(10 \%)$ were used in this study. The rice husks were collected from a local rice milling industry in Igbemo-Ekiti, Ekiti State $\left(7^{0} 4^{\prime} 0^{\prime \prime} \mathrm{N}, 5^{0} 21^{\prime} 0^{\prime \prime} \mathrm{E}\right)$, while saw dust and metallic chips were sourced for within Omu-Aran, Kwara State ( $8^{0} 8$ ' $20^{\prime \prime} \mathrm{N}, 5^{0} 6^{\prime}$ ' " E).

\section{Method}

Rice husks and saw dusts were sun-dried for three days in order to remove surface moisture. Both rice husks and saw dust were pulverized and screened to below $1.5 \mathrm{~mm}$ sieve size (ASTM standard) which was used in the production of the particleboard. The mould used was constructed using wood of dimension $100 \mathrm{~mm} \times 100 \mathrm{~mm} \times 10 \mathrm{~mm}$. The inner part of the mould was covered with nylon sheet so that the particleboard produced might have a fine surface finish. A digital weighing scale (HX 302T) with 0.01g accuracy was used in determining the amount of mass for each composites batch as presented in Table 1. Hydraulic press was used to compress the blend of the rice husks, saw dust, metallic chips and the adhesives which have already been placed in the prepared wooden mould.

\section{Production and evaluation of properties of the particleboard}

The variables used in this work are rice husk and saw dust which are mixed in various proportion by percentage ranging from 0:100, 10:90, 20:80, 30:70, 40:60, 50:50, 60:40, 70:30, 80:20, 90:10 and 100:0, respectively. The percentage amount of the adhesive/binders (UF and gelatinized starch) and the metallic chips $(1 \mathrm{~kg})$ were kept constant for each of the samples. To produce the particle board, the weighing balance was used to weigh the rice husk, saw dust, starch and or UF, and metallic chips. For each of the samples, the mixtures were thoroughly mixed manually using wooden stirrer. 
The mixture was thereafter poured into the wooden mould and compressed using hydraulic press. Through this process, the particleboard sample formed took the shape of the mould cavity which gave a smooth surface. Each sample was allowed to dry for 2 days and was carefully removed from the mould. After each of the particleboard samples was removed from the mould, it was sun-dry for 10 days. The physical properties (density and moisture content) of the particleboards produced were evaluated. The density of the particleboard was calculated using the measured mass and volume obtained from the dimension ( $100 \mathrm{~mm} \times 100 \mathrm{~mm} \times 10 \mathrm{~mm}$ ) of the particleboards using Eqns. (1) and (2)

$$
\begin{aligned}
& \text { Volume }=\text { Length } \times \text { Breadth } \times \text { Thickness } \\
& \text { Density }=\frac{\text { Mass of the particleboard }}{\text { Calculated Volume of the particleboard }}
\end{aligned}
$$

The masses of the samples are determined before and after sun drying. Moisture content is calculated using Eq. 3.

$$
\text { Moisture Loss }=\left(\frac{m_{i}-m_{o}}{m_{i}} \times 100\right) \%
$$

Where $m_{i}$ and $m_{o}$ are masses of the sample before and after sun drying respectively.

The mechanical properties such as static bending test, modulus of elasticity (MOE), modulus of rupture (MOR) and internal bonding strength (IBS) were determined according to ASTM D 1037 [13] standard; using a Universal Testometric machine (M500-50AT model).

Equations (4), (5) and (6), respectively were used in the determination of MOE, MOR and IBS from the load-deflection curves.

$$
\begin{aligned}
& M O R=\frac{3 P_{b} L}{2 b h^{3}} \\
& M O E=\frac{P_{b p} L^{3}}{4 b h^{3} Y_{p}} \\
& I B S=\frac{P_{s}}{b L}
\end{aligned}
$$

where $P_{b}$ is maximum load $(\mathrm{N}), P_{b p}$ is load at the proportional limit $(\mathrm{N}), Y_{p}$ is deflection corresponding to $P_{b p}, P_{s}$ is Rupture load $(\mathrm{N})$, while $\mathrm{b}, \mathrm{h}, \mathrm{L}$ are width, thickness and length of specimen respectively.

\section{Results and Discussion}

\section{Physical properties}

The physical properties (Mass, density and moisture content) of the particleboards for different formulation ratio are presented in Table 1. The mass of the particleboards ranged from $0.3126 \mathrm{~kg}$ to $0.4135 \mathrm{~kg}$ which resulted in density variation from $762.86 \mathrm{~kg} / \mathrm{m}^{3}$ to $801.60 \mathrm{~kg} / \mathrm{m}^{3}$ for the particleboards. The moisture content value verified varied from $9.22 \%$ to $9.98 \%$. According to Melo and Del Menezzi [14], the physical properties are greatly influenced with low variation in moisture content which will enable greater reliability of the particleboards produced. This low moisture variation was obtained in this study. The mass of the boards varied significantly from each other due to the variations in their composition. The mean density of particleboards with more sawdust was computed to be $762.86 \mathrm{~kg} / \mathrm{m}^{3}$ while the mean density of particleboards with more of 
rice husk was verified to be $801.60 \mathrm{~kg} / \mathrm{m}^{3}$. This implied that an increase in rice husk content in the admixtures led to an increase density for the particleboard. The densities of the particleboards were in the required range $\left(600 \mathrm{~kg} / \mathrm{m}^{3}\right.$ to $\left.850 \mathrm{~kg} / \mathrm{m}^{3}\right)$ for medium particleboards as stipulated by the values ANSI A 208.1 [15] standard. Through Eqns. (1) and (2), the volume and density of each of the composite sample were determined, respectively. Table 1 shows the densities of each of the sample. It is observed that the density of samples $\mathrm{E}$ and $\mathrm{F}$ are higher when compared to other samples. The composite samples densities gave a favourable result since there was no lesser density when compared with the ANSI A 208.1 [15] standard. However, the composite sample E has a higher density value of $876.2 \mathrm{~kg} / \mathrm{m}^{3}$ above the required medium particleboard as stated by ANSI 208.1 standards. Hence, the sample E will be highly useful for both general purpose and interior fitments when compared with other samples. Density and moisture content have significance influences in determining the mechanical properties of particleboards and the high density obtained for the particleboard produced in the present study is an indication of strong and durable particleboard [12].

\section{Table 1: Physical properties of different mix ratio of particleboard}

\begin{tabular}{|c|c|c|c|c|}
\hline $\begin{array}{c}\text { Sample } \\
\text { ID }\end{array}$ & $\begin{array}{c}\text { Sawdust: Rice husk } \\
(\%)\end{array}$ & $\begin{array}{c}\text { Mass } \\
(\mathrm{kg})\end{array}$ & $\begin{array}{c}\text { Density } \\
\left(\mathrm{kg} / \mathrm{m}^{3}\right)\end{array}$ & $\begin{array}{c}\text { Moisture } \\
\text { Content }(\%)\end{array}$ \\
\hline A & $0: 100$ & 0.3262 & 805.80 & 9.98 \\
\hline B & $10: 90$ & 0.3599 & 799.80 & 9.81 \\
\hline C & $20: 80$ & 0.4135 & 735.11 & 9.73 \\
\hline D & $30: 70$ & 0.3560 & 791.10 & 9.67 \\
\hline E & $40: 60$ & 0.3943 & 876.20 & 9.61 \\
\hline F & $50: 50$ & 0.3741 & 831.30 & 9.58 \\
\hline G & $60: 40$ & 0.3324 & 738.70 & 9.56 \\
\hline H & $70: 30$ & 0.3126 & 694.70 & 9.46 \\
\hline I & $80: 20$ & 0.3696 & 821.30 & 9.45 \\
\hline J & $90: 10$ & 0.3536 & 785.80 & 9.42 \\
\hline K & $100: 0$ & 0.3482 & 773.80 & 9.22 \\
\hline
\end{tabular}

\section{Moisture content}

In the determination of the amount of moisture content loss, the masses of the composite samples were determined by direct weighing before sun drying and after sun drying. The results as presented in Table 1 were obtained using Eq. 3. It can be said based on Eq. 3 used that there was reduction in the masses of the samples after sun drying. This can be attributed to reduction of the moisture content in the composite samples after being sun dried. It was observed that Sample A (100\% rice husk) with $9.98 \%$ has the highest percentage of moisture loss. According to Odusote et al. [16], this may be due to poor water retention during faster rate drying process. This may also be due to inappropriate compaction due to the presence of pores in the rice husk compact. When the presence of pores in the material is high, the material tends to lose moisture at a faster rate [16]. It was observed that the moisture loss of the samples reduces as the rice husk composition in each sample reduces. Hence, rice husk have low water retention capacity compared with saw dust. This can be due to possibly to good compaction and better homogeneity of the sawdust and rice husk.

\section{Mechanical Properties}

The peak force of the compression test that each particleboard can withstand before failure are presented in Table 2. The mean peak force for particleboards with more rice husk particles was evaluated to be $621.24 \mathrm{~N}$ while the average of peak forces for boards with more sawdust particles was evaluated to be $685.50 \mathrm{~N}$. The maximum peak force was obtained to be $1745.69 \mathrm{~N}$ (Sample F) and the minimum peak force was observed to be $338.94 \mathrm{~N}$ (Sample B). The maximum peak force obtained may be due to the adequate compaction of both the sawdust and the rice husk while the minimum peak force can be due to inadequate compaction. Based on this study, it cannot be 
ascertained that the compression strength of a material will be reduced by the amount of sawdust present in a composite of rice husk and saw dust.

Table 2: The peak forces that the produced particleboard can withstand under compression test

\begin{tabular}{|c|c|c|}
\hline $\begin{array}{c}\text { Sample } \\
\text { ID }\end{array}$ & $\begin{array}{c}\text { Sawdust: Rice husk } \\
(\%)\end{array}$ & Peak Force (N) \\
\hline A & $0: 100$ & 603.02 \\
\hline B & $10: 90$ & 338.94 \\
\hline C & $20: 80$ & 855.92 \\
\hline D & $30: 70$ & 734.37 \\
\hline E & $40: 60$ & 819.23 \\
\hline F & $50: 50$ & 1745.69 \\
\hline G & $60: 40$ & 581.83 \\
\hline H & $70: 30$ & 413.20 \\
\hline I & $80: 20$ & 894.08 \\
\hline J & $90: 10$ & 661.19 \\
\hline K & $100: 0$ & 877.21 \\
\hline
\end{tabular}

\section{MOR, MOE and IBS in comparison with different standards}

The maximum MOR obtained was that of sample E while the minimum value was obtained to be that of sample B as shown in Table 3. By comparison with EN 312-2 [17] standard, MOR requirement is $11.5 \mathrm{MPa}$. Composite samples $\mathrm{C}, \mathrm{E}, \mathrm{G}, \mathrm{H}$ and $\mathrm{J}$ met the requirement in which their values range between 12.22 $\mathrm{MPa}$ and $26.08 \mathrm{MPa}$. Based on ANSI A 208.1 [15] standard, the requirement of MOR is $12.5 \mathrm{MPa}$ as minimum. From the composite samples that met with EN 3122 standard, only composite sample G failed the requirement when compared with ANSI A 208.1 [15] standard.

Table 3: MOR, MOE and IBS for the different mix ratio of sawdust and rice husk

\begin{tabular}{|c|c|c|c|}
\hline Composites & $\begin{array}{c}\text { Modulus of Rupture } \\
(\mathrm{MPa})\end{array}$ & $\begin{array}{c}\text { Modulus of elasticity } \\
(\mathrm{MPa})\end{array}$ & $\begin{array}{c}\text { Internal bonding strength } \\
(\mathrm{MPa})\end{array}$ \\
\hline $\mathrm{A}$ & $9.04 \pm 0.53$ & $1447.36 \pm 68$ & $0.27 \pm 0.03$ \\
\hline $\mathrm{B}$ & $5.08 \pm 0.41$ & $753.86 \pm 35$ & $0.19 \pm 0.01$ \\
\hline $\mathrm{C}$ & $12.83 \pm 0.88$ & $3980.11 \pm 40$ & $0.39 \pm 0.03$ \\
\hline $\mathrm{D}$ & $11.02 \pm 0.55$ & $4124.04 \pm 48$ & $0.32 \pm 0.05$ \\
\hline E & $26.08 \pm 0.23$ & $3700.41 \pm 47$ & $0.72 \pm 0.04$ \\
\hline F & $8.71 \pm 0.23$ & $1599.01 \pm 42$ & $0.28 \pm 0.01$ \\
\hline G & $12.22 \pm 0.45$ & $2645.34 \pm 52$ & $0.33 \pm 0.02$ \\
\hline H & $13.40 \pm 0.67$ & $1747.92 \pm 52$ & $0.52 \pm 0.07$ \\
\hline I & $9.90 \pm 0.27$ & $1525.70 \pm 60$ & $0.34 \pm 0.03$ \\
\hline J & $13.14 \pm 0.45$ & $2011.39 \pm 39$ & $0.31 \pm 0.04$ \\
\hline K & $6.18 \pm 0.45$ & $3523.66 \pm 69$ & $0.13 \pm 0.01$ \\
\hline
\end{tabular}

Table 3 also shows that composite sample D has the maximum MOE while composite sample B has the least MOE. Based on EN 312-2 [17] and USDA [18] standards, MOE requirement for furniture manufacturing is $1600 \mathrm{MPa}$ and $1700 \mathrm{MPa}$ respectively. Composite samples $\mathrm{C}, \mathrm{D}, \mathrm{E}, \mathrm{G}, \mathrm{H}, \mathrm{J}$ and $\mathrm{K}$ met this requirement whereas samples A, B, F and I failed the requirement. Similarly, sample E gave the highest internal bonding strength (IBS) while sample B gave the least as shown Table 3. This might be due to inadequate bonding or compaction of the composites.

A parameter that indicates the interaction between the particles and the adhesive used which invariably have influence on the physical and mechanical properties obtained in this work is the internal bonding strength. Based on EN 312-3 standard [19], the results of the internal bonding 
strength of this work met the IBS requirements for general purpose and interior fitments respectively, which are $0.24 \mathrm{MPa}$ and $0.35 \mathrm{MPa}$. However, composite samples $\mathrm{B}$ and $\mathrm{K}$ failed to meet up with the standard for general purpose. Moreover, composite samples $\mathrm{C}, \mathrm{E}$ and $\mathrm{H}$ met the requirement for both the general purpose and the interior fitments.

From observation samples $\mathrm{C}, \mathrm{E}$ and $\mathrm{H}$ may be recommended for manufacture of particleboards since it passed all the standard requirements for MOR, MOE and IBS. It can be said that some of the composite samples that do not meet up with the requirements might be due to the improper mixture and or compaction of the constituting materials. According to Ndazi et al. [3], for the minimum requirement to be met, the interfacial bond strength must be increased between the rice husk and the saw dust together with the adhesives used. This will help to improve the mechanical properties of the produced particleboards so as to meet the minimum requirements. It is important that the rice husk particles be modified as it has been established that increase in particle size of rice husk will reduce the mechanical properties of particleboards produced [20]. Moreover, the metallic chip incorporated in the mixture has no negative effect on the strength of the particleboards.

\section{Conclusion}

From this study, it has been established that it is possible to produce composite particleboards from the admixture of rice husk and saw dust with the help of UF that will meet the required standards established for general purpose and interior fitments. Samples C, E and H values for MOR, MOE and IBS met with the EN, ANSI A 208.1 and USDA standards. For other composite samples, this study suggests that the interfacial bond strength between the composite particleboards produced should be increased in order for all the samples to successfully meet up with the minimum requirements of the three standards used in this study. The interfacial bond strength can be increased by reducing the particle size of both the rice husk and the sawdust and increasing the amount of adhesives used. This will help improve the physical and chemical interaction of the particles. Further study is necessary to improve the mechanical properties of the produced particleboards.

\section{References}

[1] J.A. Youngquist, A.M. Krzysik, E.W. English, H.N. Spelter and P. Chow, Agricultural fibres in composition panels. In: Proceedings of the 27th International particles board/composites materials symposium, Pullman, Washington: Washington State University, (1996) 133-152.

[2] A.C. Johnson and Y.B.D.N. Yunus, Particleboards from Rice Husk: a brief introduction to Renewable materials of Construction, (2009) 12-14.

[3] B.S. Ndazi, J.V. Tesha, S. Karlsson and E.T.N. Bisanda, Production of rice husk composite with Acacia mimosa tannin-based resin. Journal of material science. 41(21) (2006) 6978-6983.

[4] V. Laemlaksakul, Physical and mechanical properties of particleboard from Bamboo waste. International Journal of Chemical, Molecular, Nuclear, Materials and metallurgical Engineering, World Academy of Science, Engineering and Technology. 4(4) (2010) 276-280.

[5] M. Rizki, Y. Tamai, Y. Takashi and M. Terazawa, Scrutiny on physical properties of sawdust from tropical commercial wood species: Effects of Different Mills and Sawdust's Particle Size. Journal of Forestry Research. 7(1) (2010) 20-23.

[6] O.M. Aina, A.C. Adetogun and K.A. Iyiola, Heat energy from value-added sawdust briquettes of albizia zygia, Ethiopian Journal of Environmental Studies and Management. 2(1) (2009).

[7] X. Liu, X. Chen, L. Yang, H. Chen, Y. Tian and Z. Wang, A review on recent advances in the comprehensive application of rice husk ash. Research on Chemical Intermediates, (2016) 1-21. 
[8] V.I.E. Ajiwe, C.A. Okeke, S.C. Ekwuozor and I.C. Uba, A Pilot Plant for Production of Ceiling Boards from Rice Husks, Bioresource Technology. 66(1) (1998) 41-43.

[9] R.R. Melo, E.J. Santini, C.R. Haselein and D.M. Stangerlin, Propiedades fisico-mecanicas de paineis aglomerados produzidos con diferentes proporcoes de Madeira e casca de arroz. Ciencia Florestal, 19(4) (2009) 449-460.

[10] T.E. Omoniyi, Development and Evaluation of Bagasse Reinforced Cement Composite Roofing Sheets. Unpublished Ph.D. Thesis, Department of Agricultural Engineering, University of Ibadan, (2009).

[11] H. Poblete, Tableros de partículas, Facultad de Ciencias Forestales, Universidad Austral de Chile. Editorial El Kultrún, Valdivia, Chile, (2001) p. 177.

[12] R.R. Melo, D.M. Stangerlin, R.R.C. Santana and T.D. Pedrosa, Physical and Mechanical Properties of Particleboard Manufactured from Wood, Bamboo and Rice Husk, Material research. (2014)

[13] American Society for Testing and Materials - ASTM. Standard testing methods for evaluating wood-base fibre and particle panel materials: specification ASTM D 1037-98. Philadephia: ASTM (1998).

[14] R.R. Melo and C.H.S. Del Menezzi, Influencia da massa especifica nas propiedades fisicomecanicas de paineis aglomerados. Silva Lusitana. 18(1) (2010) 59-73.

[15] American National Standard Institute - ANSI. (1993) Mat-formed wood particleboard: Specification ANSI A 208.1.1993.

[16] J.K. Odusote, S.A. Onowuma and E.A. Fodeke (2016). Production of paperboard briquette using waste paper and sawdust, The journal of engineering research (TJER). 13(1) (2010) 80-88.

[17] EN 312-2 - Particleboard-Specification - Part 4: Requirements for general purpose boards for use in dry conditions, European Standard Committee, Brussel. (1996)

[18] United State Department of Agriculture USDA - Wood Handbook: Wood as an engineering material, Washington, (2010) p.243.

[19] EN 312-3 - Particleboard-Specification - Part 3: Requirements for boards for interior fitments (including furniture) for use in dry conditions, European Standard Committee, Brussel. (1996)

[20] J.O. Osarenmwinda and J.C. Nwachukwu, Effect of particle size on some properties of rice husk particleboard. Advanced Material Research, 18-19 (2007) 43-48. 